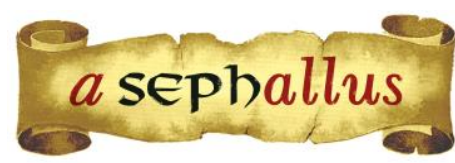

Revista aSEPHallus de Orientação Lacaniana

Núcleo Sephora de Pesquisa sobre o Moderno e o Contemporâneo

ISSN $1809-709 \mathrm{X}$

\begin{abstract}
Perspectivas clínicas do supereu: desdobramentos desse imperativo categórico no tratamento psicanalítico ${ }^{1}$
\end{abstract}

Virgínia Célia Carvalho da Silva Orcid: 0000-0001-8145-5565

Doutora e Mestre em Estudos Psicanalíticos pela Universidade Federal de Minas Gerais / UFMG (Belo Horizonte, Minas Gerais, Brasil) Pesquisadora do Núcleo Interdisciplinar de Estudos em Psicanálise e Educação / NIPSE na Faculdade de Educação / FaE da Universidade Federal de Minas Gerais / UFMG (Belo Horizonte, Minas Gerais, Brasil) Integrante da Comissão Nacional do Centro Interdisciplinar de Estudos sobre a Criança / CIEN (Belo Horizonte, Minas Gerais, Brasil)

Psicanalista

E-mail: professoravirginiac@gmail.com

Resumo: O presente trabalho apresenta um percurso sobre o conceito de supereu, enfocando-o sob seu aspecto clínico. Este se desdobra em três dimensões: a primeira, que diz respeito às suas manifestações sintomáticas que frequentemente aparecem na demanda inicial de análise; a segunda, que inclui o analista como depositário da exigência superegoica, e a terceira que leva em conta o final da análise e os destinos do supereu. Destaca-se, nesse texto, o conceito em sua vertente pulsional, de exigência de satisfação, o que vai muito além de tomá-lo apenas como instância herdeira do Édipo que promove a interiorização da lei, como é predominantemente entendido.

Palavras-chaves: Supereu; fantasia; clínica psicanalítica; final de análise.

Perspectives cliniques du Supereu: déploiement de cet impératif catégorique dans le traitement psychanalytique: Le présent travail présente une recherche clinique sur le concept de surmoi. Celle-ci se déroule en trois dimensions: la première, qui concerne ses manifestations symptomatiques qui apparaissent fréquemment dans la demande d'analyse initiale; la seconde, qui inclut l'analyste comme dépositaire de l'exigence surmoïque, et le troisième, qui prend en compte la fin de l'analyse et les destinées du surmoi. Dans ce texte, l'accent est sur mis concept dans son aspect pulsionnel, d'exigence de satisfaction, ce qui va bien au-delà de le comprendre uniquement comme l'héritier de l'CEdipe qui favorise l'intériorisation du loi, conformément à la définition la plus répandue.

Mots-clés: Surmoi; fantaisie; clinique psychanalytique; fin d'analyse.

Clinical Perspectives of the Supereu: unfolding of this categorical imperative in psychoanalytic treatment: This paper presents a course on the concept of superego, focusing on its clinical aspect. This unfolds in three dimensions: the first, which concerns its symptomatic manifestations that frequently appear in the initial demand for analysis; the second, which includes the analyst as the depositary of the superegoic requirement, and the third, which takes into account the end of the analysis and the destinies of the superego. In this text, the concept is explained its drive aspect, of satisfaction requirement, which goes far beyond taking it only as the heir to the Oedipus that promotes the internalization of the law, as is most commonly defined.

Keywords: Superego; fantasy; psychoanalytic clinic; end of analysis.

Revista aSEPHallus de Orientação Lacaniana. Rio de Janeiro, 15(30), 101-122, mai. 2020 a out. 2020.

Perspectivas Clínicas do Supereu: desdobramentos desse imperativo categórico no tratamento psicanalítico

Virgínia Célia Carvalho da Silva 


\section{Perspectivas Clínicas do Supereu: desdobramentos desse imperativo categórico no tratamento psicanalítico}

Virgínia Célia Carvalho da Silva

Apesar das especificidades, tanto em Freud quanto em Lacan, a noção de supereu se destaca em função de suas incidências clínicas. Afinal, não foi por outra via que Freud o pontuou como tal. Miller (2009) ressalta como o supereu, em seu estatuto de novidade na teoria freudiana, marca uma diferença em relação ao que existia até então: trata-se da inauguração de uma ética que não corresponde ao bem-estar. Isto porque a referida noção indica que o sujeito se apega "a algo que não Ihe faz bem, a algo que não colabora com seu bem-estar" (Miller, 2009, p. 139).

Jésus Santiago (2020), na apresentação intitulada Cristianismo, um supereu todo-amor, na Orientação Lacaniana promovida pela Escola Brasileira de Psicanálise, lembra que o conceito de supereu tem sua fonte no fator constante da pulsão, essa força que é uma exigência de satisfação dirigida ao próprio corpo. Ele destaca que para além de herdeiro do Complexo de Édipo, o supereu é herdeiro do Isso, o que veremos nesse artigo. Nesse sentido, alerta que não podemos confundir o supereu como o pai, ou mesmo como um "princípio normalizador da censura" (Santiago, 2020, s/p). Ao fazer essa confusão, "apaga-se o que se formula como efeitos do Complexo de Édipo, em Bate-se numa criança - sob o modo de cicatrizes ou sequelas que se implantam nas fantasias de fustigação, de autoflagelo e outras figurações perversas" (Santiago, 2020, s/p). Veremos, no presente trabalho, como a dimensão de imperativo de gozo e de lei insensata do supereu se apresenta de modo importante já no desenvolvimento de Freud.

Nesse sentido, considerando que o supereu retira sua força da pulsão, suas manifestações exigentes são centrais no tratamento psicanalítico, em especial na produção de sintomas. Podemos, portanto, localizar nesse conceito três dimensões clínicas que são fundamentais na direção do tratamento. A primeira refere-se às referidas manifestações superegoicas das quais o sujeito que procura análise é testemunha e que se apresentam através do sentimento de culpa, do remorso, do masoquismo moral, da reação terapêutica negativa, da compulsão à repetição, da censura, da autocrítica, etc. A outra dimensão diz respeito a uma previsão clínica de que ao longo do tratamento, a transferência do analisante situará seu supereu na figura do analista. A terceira refere-se à ideia de que, ao se despedir de seu analista, esse sujeito terá de volta a seu encargo os resíduos do supereu "que é um resíduo intratável" (Santiago, 2020, s/p). Sabemos que um saber se haver com esses restos é decisivo para que se possa concluir efetivamente uma análise. Assim, dada a relevância clínica dessa noção, investigá-la nos parece essencial.

\section{O "Imperativo Categórico"}

O supereu tem início nas pesquisas de Freud, a partir do que sua observação clínica o remetia às descrições de Immanuel Kant (2004) sobre o "imperativo categórico". Embora seja possível 
localizar o estabelecimento desse conceito apenas em 1923, é importante demarcar que essa ideia esteve presente no texto freudiano desde muito cedo.

Esse "imperativo categórico" representa, em Kant (2004), um dever incondicional. Estudando a moralidade, o filósofo inaugura um novo modo de pensá-la, levando em conta não as ações visíveis do homem, mas seus princípios íntimos. Ele desbanca a ideia de que há no mundo virtudes verdadeiras, sustentando que as ações e as vontades humanas são determinadas por uma razão apriorística que se expressa como fórmula através de imperativos. Estes exprimem a relação entre leis objetivas (e não subjetivas) do querer em geral e a imperfeição subjetiva da vontade humana (Kant, 2004). Os imperativos auxiliam no julgamento de uma ação que, para ser considerada boa, deve estar em conformidade com a lei moral universal, aplicada a todos. Nesse sentido, os imperativos são fórmulas do mandamento da razão e se expressam pelo verbo "dever", regulando as ações humanas.

Os imperativos podem ser hipotéticos ou categóricos. São hipotéticos quando representam a necessidade prática de uma ação possível como meio de conseguir qualquer outra coisa que se quer ou são categóricos quando, sem relação com nenhum outro fim, representam uma ação como objetivamente necessária, um fim em si mesma. Sempre que se buscar uma frase imperativa para exemplificar o imperativo categórico, aparecerá a possibilidade da existência de uma causa subjacente à ação determinada por tal frase, o que a classificará como imperativo hipotético, daí a dificuldade de exemplificá-lo.

Embora haja uma impossibilidade prática nessa dificuldade, na visão de Kant (2004), sabemos exatamente o que contém um imperativo categórico: uma lei universal e necessária. Trata-se de um imperativo absoluto e, nesse sentido, o que ele transmite não é senão a necessidade da máxima - o princípio subjetivo da ação - que ordena ao sujeito que se conforme com a lei universal. Isto está explicitado na seguinte formulação proposta por Kant (2004) para o imperativo categórico: "age só segundo a máxima tal que possas ao mesmo tempo querer que ela se torne lei universal" (Kant, 2004, p. 10) ou, em outras palavras "age como se a máxima da tua ação devesse se tornar, pela tua vontade, lei universal da natureza" (Kant, 2004, p. 10).

Kant (2004) se interroga sobre o motivo pelo qual o homem, ao buscar sua felicidade e satisfação, não se ordena a fazer o que deseja. Para Campos (2015), essa ideia seria uma intuição sobre a existência de uma instância paradoxal no próprio homem que joga contra ele próprio, impossibilitando a busca pela felicidade no seu bem-estar. Assim, mesmo que Kant não tenha dito do supereu, deixa todas as pistas para Freud fazê-lo. Convém ressaltar, entretanto, que embora Freud (1923/1996g) tenha feito uma equivalência entre o supereu e o imperativo categórico, há uma diferença entre eles. O supereu não é um imperativo categórico, e sim funciona como um imperativo categórico - não se restringe a ele. Veremos essa diferenciação ao nos aprofundarmos um pouco mais no percurso de Freud em torno do tema.

\section{Primórdios de uma instância imperativa}


Como já indicamos, o supereu esteve presente como ideia no texto freudiano muito antes de sua notação em 1923/1996g. É possível verificar nos primeiros casos freudianos o vislumbre de uma força aniquiladora no destino de todo sujeito sobre os nomes de sacrifício, automartírio, autopunição e delírio de ser notado (Gerez-Ambertín, 2003). Tal força se inscreve sob a noção de "consciência moral", está vinculada ao parricídio, à culpa e ao castigo. Também no Projeto para uma Psicologia Científica, de 1895, o que se percebe é que as noções de pecado original, das Ding e trauma seriam como ancestrais do supereu, já que a ideia de Freud (1892-1899/1996a) é a de que o desamparo inicial do ser humano é a fonte primordial de seus motivos morais.

Um outro ancestral seria o "sentimento inconsciente de culpa", que Freud (1892-1899/1996a, p. 316) trabalha ao se referir a Hamlet, peça de Shakeaspeare. Nesta, o fantasma do rei da Dinamarca, assassinado por seu próprio irmão, quem se esposou da rainha logo após sua morte, exige do filho que o vingue. Há, não obstante, uma hesitação nessa vingança por Hamlet, que se apresenta bastante atormentado. Freud (1892-1899/1996a) acredita que se Hamlet procrastina na vingança é porque ele próprio havia desejado perpetrar a mesma ação contra seu pai, em função de sua paixão pela mãe: "sua consciência [moral] é seu sentimento inconsciente de culpa" (Freud, 18921899/1996a, p. 316)².

A primeira referência freudiana ao imperativo categórico de Kant aparece na Traumdeutung a Interpretação dos Sonhos -, quando Freud (1900/1996b, p. 103) se dedica a analisar "o sentido moral nos sonhos". A "personalidade moral" deixaria de funcionar quando se está sonhando? Para responder à polêmica questão, Freud (1900/1996b) cita Hildebrant que diz que: "o imperativo categórico de Kant é um companheiro que nos segue tão de perto em nossos calcanhares que não nos podemos nos ver livre dele nem quando adormecidos" (Hildebrant, citado por Freud, 1900/1996b, p. 103). Embora não desenvolva o tema em 1900, é possível notar que essa ideia se aproxima do que ele irá enunciar em 1923/1996g, ao afirmar que o supereu se manifesta sobre o eu na forma de um imperativo categórico. Além dessa articulação, na Traumdeutung também encontramos pelo menos mais dois elementos que demarcam uma divisão do sujeito e que se referem ao que mais tarde foi nomeado como supereu: a censura que atua sobre o eu ao acordar e aqueles sonhos provenientes de um desejo inconsciente de autopunição.

O imperativo categórico de Kant também está presente em Totem e Tabu (Freud, 1913/1996c). Escrito a partir dos ensinamentos de Darwin, esse texto forja o mito da civilização, inaugurando a ideia de um pai violento e ciumento que guarda para si todas as fêmeas da horda e que expulsa seus filhos assim que crescem. Juntos, esses irmãos expulsos, certo dia, retornam à horda, matam o pai tirânico e o devoram, colocando fim à horda patriarcal. Além de temido e odiado, o pai era invejado e tomado como modelo. Desse modo, a ingestão de sua carne representava um movimento identificatório de incorporação da força paterna. Entretanto, diante do amor que sentiam pelo pai, após se livrarem dele, precisam lidar com o remorso proveniente dessa atitude: "o pai morto tornou-se mais forte do que o fora vivo" (Freud, 1913/1996c, p. 146). Em outras palavras, há um 
resto do pai impossível de ser digerido, o que torna necessária a instituição de um totem que funcione como substituto do pai morto. Nesse sentido, proíbem a morte do totem, renunciam a seus frutos e abrem mão das mulheres que antes eram do pai. O totem poderia ser um animal, um vegetal ou um fenômeno natural que guardasse alguma relação particular com o clã.

Do assassinato do pai, além da instituição do totem, faz-se necessária a criação de dois tabus: o do homicídio e o do incesto. Freud (1913/1996c) lembra que ao mesmo tempo em que o tabu - termo polinésio - é sagrado e consagrado, é misterioso, perigoso, proibido e impuro. Ele se constitui como restrição e se impõe por conta própria, não se baseando em uma ordem divina ou moral. Os tabus são proibições sem fundamento e de origem desconhecida, mas funcionam "como o 'imperativo categórico' de Kant, que opera de uma maneira compulsiva e rejeita quaisquer motivos conscientes" (Freud, 1913/1996c, p. 18). Para Scheijtman, o "caroço do pai" (Scheijtman, 2004, p. 14), isso que não se mata dele e que faz necessário o totem e os tabus, seria o próprio supereu.

Em 1914/1996d, não há menção ao termo supereu, mas a um agente psíquico especial distinto do eu e que ao mesmo tempo atua sobre ele, a fim de assegurar a satisfação narcísica proveniente do ideal. É um agente que vigia e critica nossas intenções e estaria relacionado tanto a consciência moral quanto ao teste de realidade (Freud, 1914/1996d). O agente psíquico especial se reconhece na clínica da neurose na voz silenciosa da consciência e do sentimento de culpa, e na psicose, em voz alta, no delírio de ser notado e vigiado. Poderíamos pensar que na civilização contemporânea haveria mais manifestações superegoicas desse último tipo?

Esse agente psíquico tem a função de aumentar as exigências para com o eu de modo que ele possa cumprir aquilo que está determinado no campo do "ideal do eu", como propõe Campos (2015). O referido ideal pode ser tomado como o que o eu projeta para si como uma substituição do narcisismo primário perdido de sua infância e é o que une as pessoas libidinalmente em torno de um grupo, como Freud (1930/2020) pontua mais adiante. Em sua metapsicologia, de 1915/2010, também há menção a um agente crítico que se separa do eu e se coloca contra ele, julgando-o e recriminando-o no caso da melancolia, em que diante de uma perda, a sombra do objeto recai sobre o eu (Freud, 1915/2010).

Feito esse percurso, é possível perceber que, mesmo antes de 1923/1996g, encontramos figuras que apontam para uma instância que indica a presença de uma divisão subjetiva. Dentre elas está a ideia de sacrifício, automartírio, autopunição, delírio de ser notado, consciência moral, sentimento inconsciente de culpa, tabu, agente psíquico especial, agente crítico e imperativo categórico.

\section{0 paradoxo do Supereu em Freud}

Em 1923, Freud sente necessidade de rever sua tópica sobre o aparelho psíquico. É no texto O eu e o Isso (Freud, 1923/1996g) que ele dá nome ao supereu, inicialmente igualando-o ao ideal do eu, embora the retire a responsabilidade de promover o teste da realidade, distanciando-o da ideia de 
consciência moral. A segunda tópica circunscreve-se a três instâncias psíquicas: o Isso, o supereu e o eu. Freud (1923/1996g) localiza o Isso como o lugar das paixões e das pulsões, ou seja, uma parte da mente que se comporta como se fosse inconsciente, mas que não está separada do eu. Este, por sua vez, é a parte do Isso que foi modificada pela influência do mundo externo e que representa a razão. É sobretudo corporal e aplica sua influência do mundo externo ao Isso, preconizando o princípio de realidade - aquele que visa o adiamento da busca por prazer e uma tolerância maior ao desprazer. Já o supereu tem sua origem nas identificações primitivas com os pais, antes mesmo da diferenciação sexual anatômica, e ganha mais força a partir do Complexo de Édipo ${ }^{3}$ - aponta Freud (1923/1996g).

O supereu se apresenta, portanto, como um paradoxo: ao mesmo tempo em que se constitui como resíduo das primitivas escolhas do Isso, representa uma formação enérgica contra elas. A relação do supereu com o eu inclui tanto o "Você deveria ser assim (como seu pai)", como também o "Você não pode ser assim (como seu pai), isto é, você não pode fazer tudo o que ele faz; certas coisas são prerrogativas dele" (Freud, 1923/1996g, p. 47). Ou seja, ao mesmo tempo em que se fortalece no complexo edípico, é sua missão recalcá-lo.

Para Freud (1923/1996g, p. 47), o supereu "retém o caráter do pai" e quanto mais poderoso for o complexo de Édipo e mais rápido se submeter ao recalque (pela religião, pela educação e pela leitura), mais severa será a dominação do supereu sobre o eu. As apresentações clínicas dessa dominação se expressam no sentimento inconsciente de culpa e sob a forma de consciência moral. Esta se forma como interiorização da autoridade paterna e funciona como censura moral. 0 sentimento de culpa se constitui da tensão entre as exigências da consciência e os desempenhos concretos do eu, ou, em outras palavras, da distância entre o eu e o ideal do eu, que Freud, no texto de 1923/1996g iguala ao supereu.

Um outro ponto relevante é o aspecto compulsivo do supereu, que é indicado pelo fato de essa instância se manifestar sobre o eu na forma de um imperativo categórico. Freud (1923/1996g) pontua que o eu se submete ao imperativo categórico do supereu tal como uma criança esteve um dia sob a compulsão de obedecer aos pais. E se ele se submete é por ter sido em algum momento um eu frágil.

No texto de 1923/1996g, encontramos uma interessante indicação clínica, quando Freud explica que, ao longo do tratamento, é importante que o paciente possa encarnar seu supereu na figura do analista. O sucesso do tratamento depende "da personalidade do analista permitir ao paciente colocá-lo no lugar de seu ideal do eu, e isto envolve, para o analista, a tentação de desempenhar o papel de profeta, salvador e redentor do paciente" (Freud, 1923/1996g, p. 63) e isso seria totalmente oposto à proposta da psicanálise. Sabemos que alguns teóricos se ativeram a essa frase, desconsiderando a equivalência feita por Freud entre o ideal do eu e o supereu e acabaram por considerar que uma análise está bem encaminhada quando o analisante se identifica a seu analista. Conforme propõe Araújo (1990), a cura para os pós-freudianos consiste "na transformação do antigo supereu em algo ligado à realidade pela identificação com o supereu do analista" (Araújo, 1990, p. 
92). Lacan (1956-1957/1995) fez duras críticas a esse respeito, exatamente por considerar, assim como Freud, que essa ideia diverge radicalmente do propósito de uma análise que é o de se desalinhar do supereu (Campos, 2015) - como veremos posteriormente.

A reação terapêutica negativa, que se apresenta para Freud desde seu Além do Princípio de Prazer, de 1920/1996f, consiste no momento do tratamento em que os pacientes reagem inversamente a seu progresso. Ele o indica como o mais poderoso obstáculo à cura e a relaciona a um sentimento de culpa que encontra satisfação na doença, manifestando-se como uma recusa em abandonar a punição do sofrimento. Nesse panorama, o supereu estaria à serviço dessa reação, produzindo uma satisfação masoquista no eu, através de um castigo de padecer.

Freud esclarece que o sentimento de culpa surge da tensão existente entre o eu e o ideal do eu, como uma espécie de condenação egóica, assim como o sentimento de inferioridade. Na neurose obsessiva, o sentimento de culpa é super ruidoso, mas sua causa resta inconsciente por estar referido a conteúdos que devem permanecer recalcados. Na melancolia, esse sentimento obtém apoio na consciência e o eu, admitindo sua culpa, submete-se ao castigo. Já na histeria, o eu mantém à distância o material aflitivo a que se refere o sentimento de culpa e que seria alvo das críticas do supereu (Freud, 1923/1996g). Outra categoria trazida por Freud (1923/1996g) para compreendermos esse sentimento é a dos criminosos em função de um sentimento de culpa. A culpa, nesses casos vem antes do crime e não depois. 0 crime seria a tentativa de ligar o sentimento inconsciente de culpa a algo imediato e concreto, que produziria alívio.

É interessante notar que em 1923/1996g, Freud já havia se deparado com a insuficiência do princípio de prazer para explicar todos os processos mentais. Encontrou um mais além do princípio de prazer, uma tendência à repetição e um masoquismo primário que se apresentavam regidos por uma classe de pulsões ávidas por "restaurar um estado anterior de coisas" (Freud, 1920/1996f, p. 47): as pulsões de morte. Posteriormente, Freud (1930/2020) indicou que essas seriam as pulsões básicas - o que Lacan (1964/1998c) formalizou dizendo que toda pulsão é de morte. Ou seja, a pulsão, por si própria não pode se fazer representar no inconsciente. Nesse sentido, quando ela se alia a uma representação ideativa, recebe um tratamento do princípio de prazer, funcionando a serviço de Eros. Assim, pulsão de vida e de morte constituem dois aspectos de uma mesma realidade: enquanto silenciosa e desprovida de qualquer bordejamento simbólico, a pulsão se constituiria em sua dimensão de morte; quando aponta para alguma representação, estaria no campo da pulsão de vida.

Freud $(1923 / 1996 \mathrm{~g})$ considera três maneiras de tratar a pulsão de morte. Uma delas seria a de torná-la inócua, através de sua fusão com componentes eróticos. Outra maneira seria o seu desvio para o mundo externo sob a forma de agressividade e impulsos destrutivos para com os objetos da civilização. E uma terceira seria a de continuar agindo silenciosamente no próprio eu. Ao se dedicar a essa explicação, ele lembra que a moralidade costuma perpassar as tentativas de controle da pulsão, pois um indivíduo seria considerado moral se conseguisse domar suas pulsões. Desse modo, o Isso seria considerado completamente amoral, por buscar satisfação das pulsões a qualquer preço; o eu se 
esforça para ser moral, já que procura uma mediação entre a satisfação e o controle das pulsões e o supereu, para ser super moral, pode se tornar tão cruel que se coloca em paridade com o Isso. Segundo Freud (1923/1996g), quanto mais um homem tenta controlar sua agressividade para com o exterior, mais severa se torna a inclinação de seu supereu à agressividade contra o eu. Mais uma vez, é possível localizar que o supereu se apresenta como um paradoxo em Freud, o que será renovado por Lacan.

Freud aponta que o supereu surge "de uma identificação com o pai tomado como modelo" (Freud, 1923/1996g, p. 67). Nesse sentido, ele exige uma dessexualização ou uma sublimação. Ocorre, desse modo, uma "desfusão libidinal" (Freud, 1923/1996g, p. 67), ou seja, a agressividade livre de qualquer representação erótica. E, "essa desfusão seria a fonte do caráter geral de severidade e crueldade apresentado pelo ideal - o seu ditatorial 'farás'"' (Freud, 1923/1996g, p. 67).

Nesse panorama, o eu, que não é senhor de sua própria casa (Freud, 1917/1996e), deve serviço a três senhores e é ameaçado por três perigos: o mundo externo; a libido do Isso e a severidade do supereu. O que se acha por trás do pavor que o eu tem do supereu é, no fundo, um medo da consciência e também da morte, um pavor à castração. Em 1932-1933j/1996, na Dissecção da Personalidade Psíquica, Freud trabalha a ideia de um eu dividido entre um território estrangeiro externo, a realidade, e um território estrangeiro interno. Tendo como base arcaica o Isso - esse caldeirão fervilhante, o supereu se utiliza da energia caótica proveniente dessa instância para subjugar o eu, colocando-o sobre o determinismo de um imperativo impossível de ser satisfeito. Também nesse texto, há a marca de uma diferença entre o supereu e o ideal do eu, uma vez que é ação do supereu estimular o eu a alcançar a perfeição do ideal.

Freud (1926/1996i) trabalha a inibição, o sintoma e a angústia como resultados da ação do supereu, de acordo com Campos (2015). A inibição consistiria numa restrição de uma função do eu. Há funções que são inibidas a fim de que o eu evite entrar em conflito com o Isso. Dessa maneira, renuncia a se associar às pulsões provenientes do Isso, para não ter que recalcá-las. Quanto ao supereu, como um modo de autopunição, essa instância detecta e proíbe tudo o que traz êxito e lucro ao eu na esfera profissional, de modo que ele cede por inibição. Os sintomas, que são substitutos de uma satisfação pulsional não realizada, diminuem a força do eu e, nesse sentido, apaziguam as exigências superegoicas e do mundo externo. Já a angústia, relaciona-se a um supereu arcaico ainda indiferenciado do Isso. Mais uma vez, podemos nos perguntar se não seria esse supereu indiferenciado do Isso o que temos encontrado na clínica contemporânea, nas frequentes crises de angústia.

Outro texto em que Freud (1930/2020) se dedica ao supereu é o Mal-estar na cultura. Campos chega a indicar esse mal-estar como "apanágio do supereu" (Campos, 2015, p. 83), ou seja, "o efeito último das intenções do supereu" (Campos, 2015, p. 83), como um programa dele. Nesse texto de 1930/2020, Freud se dedica a estudar os paradoxos e exigências que a cultura faz à economia psíquica dos indivíduos que dela participam. Para se manter como tal, ela busca "a proteção 
do ser humano contra a natureza e a regulamentação das relações dos seres humanos entre si" (Freud, 1930/2020, p. 337). Trabalhando a serviço de Eros, em seu objetivo de unir libidinalmente os homens, ela se vê permanentemente em confronto com sua maior inimiga: a pulsão de morte. Esta, com seus impulsos agressivos e de destruição ameaça o programa civilizatório. Para que tal programa se mantenha, há a exigência de que a pulsão de morte seja inibida em sua finalidade, como aponta Freud (1930/2020).

Diante da questão sobre o destino dessa agressividade na cultura, Freud (1930/2020) evoca o supereu. Essa agressividade é assumida por uma parte do eu que se coloca contra o restante dele. Esta, que funciona de modo a pôr em ação contra o eu a mesma agressividade que ele teria gostado de satisfazer sobre os outros indivíduos é, segundo Freud (1930/2020) o supereu. Este funciona como um agente crítico e severo que representa a autoridade paterna, produzindo sentimento de culpa. Esse sentimento é novamente trabalhado por Freud (1930/2020) que o indica como necessidade de punição na luta entre o severo supereu e o eu. O sentimento de culpa se originaria, portanto, do medo de uma autoridade externa e também do medo do supereu (autoridade interiorizada). Ambas as origens se relacionam a uma renúncia pulsional e a um medo de perder o amor dessas autoridades. A diferença entre elas é apontada a partir da ideia de que mesmo que haja uma renúncia pulsional, os desejos proibidos se mantêm. Sendo o supereu onisciente desses desejos, eles não the podem ser escondidos, o que coloca uma permanente exigência de punição. Outro paradoxo do supereu se enuncia aí: quanto mais o sujeito cede de seu desejo, mais culpado se sente. A renúncia ao desejo não possui um caráter libertador, posto que sempre resta algo de irrenunciável. Nesse sentido, a ameaça de infelicidade externa, ligada à ameaça da perda do amor da autoridade, é substituída por uma permanente infelicidade interna, ligada ao sentimento de culpa.

Freud (1930/2020) pontua que o processo de cultura se sustenta no fortalecimento do sentimento de culpa já que para que os homens se unam entre si, precisam renunciar a uma quota de sua felicidade individual. Ele considera, portanto, a existência de um supereu-da-cultura que "desenvolveu seus ideais e elevou suas exigências" (Freud, 1930/2020, p. 401). No que concerne à relação entre os homens, estaria, portanto, a Ética. Esta seria uma tentativa de atendimento às ordens culturais e imperativas do supereu, como por exemplo, o imperativo de amor ao próximo, impossível de ser cumprido. É por acreditar que sempre haverá um impossível nas ordens do supereu que Freud (1930/2020) inaugura um novo modo de pensar a ética, incluindo a dimensão do desejo. Não há uma capacidade inata de o ser humano distinguir o bom do mau. Nesse sentido, o impossível inscrito no imperativo do supereu é o que, com um incessante e inconsciente sentimento de culpa, mantém o irremediável mal-estar na cultura.

Como vemos, o supereu em Freud se apresenta como um imperativo paradoxal que, ao mesmo tempo que exige renúncia, impele à satisfação punitiva que ele também veicula. Lacan pode nos ajudar a formalizar melhor esse paradoxo, assim como nos permite algumas respostas possíveis para a questão sobre o que ocorre com o supereu no final de uma análise. Freud se questionava 
sobre o final de análise desde o início de sua trajetória. Em 1900, na Carta 242 (Freud, 18921899/1996a) a Fliess menciona o caso E., atendido por ele, quem considerava haver concluído sua "carreira de paciente" com um jantar na casa do psicanalista. Escreve Freud: "seu enigma está quase totalmente solucionado; sua saúde excelente, sua essência totalmente mudada; dos sintomas permaneceu um resto, no momento" (Freud, 1892-1899/1996a, p. 48). Seu interesse pelos restos sintomáticos se segue e lemos, 37 anos mais tarde, em Análise finita e infinita, que "quase sempre há fenômenos residuais, um resquício parcial" (Freud, 1937/2017, p. 331). Como poderíamos indicar nesses restos o que permanece do supereu? Se o analisante localiza no analista seu supereu durante o tratamento, o que ocorre com o final de análise? Recorreremos a Lacan para nos auxiliar a responder essas questões.

\section{O supereu em Lacan}

Desde a iniciativa freudiana, muitos foram os teóricos que se ativeram ao supereu em seu aspecto de lei, interditor ao incesto e herdeiro do Complexo de Édipo. Lacan (1972-1973/1985), por sua vez, destacou a dimensão de "fora da lei" presente no supereu, o que se afirma para o ser falante como uma expressão imperativa e na qual ele se submete: "Goza!". Barreto (2001, p. 50) caracteriza o supereu em Freud como "essencialmente paterno, herança do Complexo de Édipo, instância da lei simbólica resultante da incorporação da proibição ao incesto, função coordenada ao desejo" e, em Lacan, como "essencialmente materno", "encarnação da lei insensata que corresponde ao desejo caprichoso da mãe, função coordenada ao gozo". Nosso percurso nos permite concluir que tanto em Freud como em Lacan o supereu se constitui dessas duas vertentes, estabelecendo seu modo paradoxal e exigente de funcionar.

Fazendo um recenseamento do supereu nos Seminários de Lacan, Campos (2015) nos auxilia pensar em alguns nomes para o Supereu: "derivado do Isso" (p. 162); "lei incompreendida" (p. 166); "tu és aquele que deves" (p. 170); incorporação do objeto (p. 172); "instância severa, que fica à espreita do sujeito" (p. 175); "um discurso afásico, primitivo e imposto sem palavras" (p. 183); "uma moral" (p. 183); algo do qual "o analista não se livra" (p. 189); "amor masoquista que impulsiona o sujeito para o fracasso" (p. 193); "voz do Outro" (p. 193); "elucubrações e distorções ao redor do eu" (p. 194); instância intratável e "imperativo de gozo" (p. 195).

O supereu é o conceito de Freud que engancha Lacan na psicanálise já em 1932, momento em que ele se dedicava à paranoia de autopunição em sua tese de medicina (Miller, 2009). Da psicose paranoica em suas relações com a personalidade (Lacan, 1932/1987) é a expressão de como um mecanismo de autocastigo culmina com um crime do supereu em que o sujeito busca matar sua própria doença. Lacan (1932/1987) também recorre ao imperativo categórico de Kant, mas para aproximá-lo do imperativo de gozo de Sade. Ele faz uma aproximação entre a Filosofia da Alcova e a Crítica da Razão Prática (Lacan 1932/1987). Para Campos (2015), embora Lacan lá mencione o supereu apenas uma vez, esse texto seria uma tese sobre o supereu, tendo em vista que aborda "a 
ideia do humor negro superegóico e o paradoxo entre o imperativo do gozo e o imperativo categórico como sendo duas faces da mesma instância" (Campos, 2015, p. 77). Isso pode ser lido no Seminário sobre a transferência: "Mostrarei-Ihes como o 'Tu deves' de Kant é substituído facilmente pela fantasia sadeana do gozo erigido em imperativo - pura fantasia, é claro, e quase derrisória, mas que não exclui em nada a possibilidade de sua ereção em lei universal" (Lacan, 1960-1961/1991, p. 378).

É a partir dessa satisfação paradoxal da pulsão de morte - o gozo, que Lacan (19721973/1985, p. 11) chega à máxima do supereu: "se o gozo não serve para nada, é apenas uma instância negativa, nada força ninguém a gozar, senão o [supereu]. O [supereu] é o imperativo de gozo - Goza!". De acordo com Miller (2009), Lacan elimina o paradoxo freudiano sobre o supereu na medida em que ele o formaliza como imperativo de gozo e não mais como função coordenada à lei do pai e ao desejo. Como esse imperativo, o supereu ordena e vocifera "Goza!". O gozo puro e absoluto, entretanto, é impossível pois o que goza não é o sujeito e sim a própria pulsão de morte que goza nele. Nas palavras de Lacan, a manifestação da pulsão se faz no "modo de um sujeito acéfalo, pois tudo aí se articula em termos de tensão, e não tem relação ao sujeito senão de comunidade topológica" (Lacan, 1964/1998c, p. 171). Assim, o que temos é uma impossibilidade.

O supereu como lei insensata leva o sujeito ao impossível e à escravidão. Ele diz Goza!, mas não como fazê-lo para consegui-lo, o que se coloca para o sujeito como um incessante "Deves!". Por essa razão é que quanto mais obediente a seu supereu, mais severo ele se torna. Se essa ordem superegoica é impossível de ser satisfeita, justamente pela característica de sem sentido que a compõe, mais o sujeito se vê compelido a obedecê-la, mais ainda o resto insatisfeito exigirá satisfação. Quanto mais escravo dessas exigências, mais guloso se torna o supereu: "a gulodice pela qual Freud denotou o supereu é estrutural - não é um efeito da civilização, mas um 'mal-estar' (sintoma) na civilização" (Lacan, 1973/2003, p. 528).

A Observação ao Relatório de Daniel Lagache é um texto importante de Lacan (1960/1998b) sobre o supereu. Neste, ele comenta a segunda tópica freudiana, trabalha com a noção de estrutura e faz, na parte destinada à ética, menção ao supereu (Miller, 2009). A dimensão vocal dessa instância merece destaque: "o supereu, em seu imperativo íntimo, é de fato 'a voz da consciência', isto é, antes de mais nada uma voz, bastante vocal, e sem maior autoridade senão a de ser uma voz grossa" (Lacan, 1960/1998b, p. 691). Através do recenseamento de Campos (2015), encontramos em Lacan (1954/1979) uma referência ao supereu arcaico de Melanie Klein, atribuindo-Ihe a característica de advir de uma palavra completamente privada de seus sentidos: "palavra reduzida a seu caroço", "estado nodal da palavra", "palavra interrompida" e "medula da palavra" (Lacan, 1954/1979, p. 125). O supereu funcionaria como um significante mestre (S1), sem articulação com nenhum outro significante (S2) que poderia promover algum sentido. Um S1 sem S2 permite que várias outras palavras surjam como ordens.

No primeiro momento em que aborda o supereu, Lacan (1954/1979) indica que essa lei com a qual ele trabalha é uma lei insensata e que chega mesmo a ser o desconhecimento da lei: ele "é a um 
só tempo a lei e sua destruição" (Lacan, 1954/1979, p. 123). A insensatez é explicada em função de sua vertente puramente imperativa e também porque a moral do neurótico é destrutiva, oprimente e quase sempre antilegal. Para o Lacan desse primeiro Seminário, se o texto da lei carrega em si algo de indecifrável, que nenhuma palavra pode alcançar, permite que todas as outras palavras queiram tentar se encaixar ali onde A palavra falta.

A lei se constrói como proibição a partir do fora da lei, ou seja, a proibição ao incesto só se instaura em função de sua existência mesma. Assim, o núcleo de uma proibição é exatamente o local em que ela não se inscreve. E, como localiza Campos (2015), Lacan, em seu Seminário 2, concebe o núcleo do supereu a partir desse núcleo de fora da lei. Nesse sentido, a lei do supereu não regula e organiza o sujeito, tal como pensavam os pós-freudianos. É uma lei que escraviza e mata o desejo, aquele que funciona como um remédio contra a angústia - perspectiva de Lacan (1958-1959/2016).

Mandil enuncia que "o supereu é um modo de fazer o Outro existir" (Mandil, 2015, p. 249). Para Santiago (2020, s/p), na apresentação já mencionada, ele "é um resíduo intratável pois enquanto imperativo de gozo, ele é resposta ao fora da lei que se institui com a morte de Deus", e "se Deus está morto, nada é permitido". O Eu espera ser recompensado por seu sacrifício pulsional com o amor pelo supereu. Mas, como a gulodice do supereu é ilimitada, o que se produz é sofrimento, o que o mal-estar na cultura testemunha.

Coelho dos Santos (2015) traz uma discussão sobre a contemporaneidade indicando que a ideia de que "é proibido proibir" apontaria para uma fantasia à céu aberto, sem necessidade de se mascarar através do sintoma: "se, como ensina Lacan, o objeto a ocupa posição de agente no discurso contemporâneo (supereu) é porque a lei do mercado impõe o rebaixamento da dignidade da Coisa (Ding) aos objetos trocáveis, à mercadoria que se compra e se vende" (Coelho dos Santos, 2015, p. 4). Ela se serve do significante supersocial, perguntando se o supereu, que seria uma instância psíquica intersubjetiva, não teria dado lugar a uma espécie de supersocial (Coelho dos Santos, Santiago \& Martelo, 2014).

Miller (2009) propõe considerarmos três aspectos do supereu: simbólico, imaginário e real. Sua vertente de lei refere-se a sua dimensão simbólica. Não se trata, entretanto, de uma lei pacificadora e socializante. É a lei como significante unário e próxima ao desejo caprichoso da mãe, antes de ser metaforizado, normalizado e nomeado pelo Nome do Pai. A vertente imaginária se apresenta no personagem feroz e obsceno que se encarna na imagem de alguém. Já a dimensão real, é localizada em seu aspecto mais profundo, o de voz, desapegada do sentido. Essas três dimensões são facilmente observadas na clínica e seu manejo nos parece fundamental.

\section{Abaixo o supereu!}

No Seminário 26, em que Lacan (1978-1979/2002), já doente e com poucas palavras, propõe pensarmos em $A$ topologia e o tempo, há uma lição em que Alain Didier-Weill é convidado a falar sobre a existência de três supereus, que podem ser representados sincronicamente na estrutura e 
diacronicamente em etapas, à espera de uma palavra que franqueie sua passagem. Nesta, DidierWeill retoma a primeira menção que Freud (1900/1996b) faz à censura, em sua Interpretação dos Sonhos. Assim, ele toma o supereu como o próprio censor. Nesse sentido, haveria um primeiro supereu cuja função seria ordenar ao sujeito: "não dirás uma palavra!"; um segundo que ordenaria "não dirás duas" e um terceiro cuja função seria "não dirás três".

Após se dedicar a interpretar um sonho seu, Freud (1900/1996b) pondera que o autor político, quando tem verdades a dizer, encontra dificuldades e, em função da censura que poderá sofrer, acaba por atenuar e distorcer a expressão de sua opinião para que ela não seja prontamente reprimida. E, quanto mais rigorosa a censura, mais amplo terá que ser o disfarce, assim como mais engenhoso será o trabalho para colocar o leitor no rastro do verdadeiro sentido. Freud (1900/1996b) traz um exemplo com a ideia de uma sociedade insatisfeita com um governante, que precisa lutar contra a opinião pública. $O$ povo quer sua demissão, entretanto, para mostrar que não precisa dar lugar ao desejo popular, o autocrata escolhe o momento para uma honraria, sem nenhuma razão que a preceda. Didier-Weill prossegue trabalhando o exemplo de Freud e diz que os sujeitos têm a sua disposição a revolta e também um saber elementar, já o rei, censor, está em uma posição de saber que comporta uma outra estrutura: ele sabe que precisa da opinião pública, mas reage de modo a não se importar com ela, para reduzir sua força. Ao não dar ênfase à frase "abaixo o ministro!", é como se o censor dissesse que esses sujeitos não são representados como sujeito por esse significante, o que elimina sua existência como tal. Ele responde, então, com uma mensagem invertida: "Viva o ministro!". A censura não querendo que a primeira palavra seja confirmada por uma segunda palavra, ou seja, que o sujeito encontre o ponto de mais além onde pode sustentar o primeiro dito que adiantou, interrompe a mensagem do sujeito.

Há, nesse primeiro tempo, uma total impossibilidade de dizer não às exigências do supereu $\mathrm{e}$ os efeitos disso são verificados na inibição, perplexidade, vergonha e angústia de se passar por ridículo. Há, então, uma grande submissão do sujeito a não poder insistir em sua palavra e esta leva a um grande sentimento de culpa. Didier-Weill (1997) caracteriza esse primeiro supereu como "medusante" - aquele frente ao qual o sujeito se encontra petrificado e siderado, como se estivesse diante de uma cabeça de Medusa. Campos (2015) indica, nesse momento, o sujeito em posição de puro objeto do gozo mortífero do supereu. É o que se observa em alguns psicóticos, petrificados sob o olhar medusante do supereu.

O segundo supereu permite insistir na primeira palavra e dizer não ao censor: "abaixo o ministro!". A frase é a mesma, porém em uma posição topológica diferente, já que abala a função da censura. Quem se encontra siderada nesse tempo é a censura, o que abre para o sujeito um vazio. Com o aniquilamento da censura, esse vazio deixa o campo aberto para algo novo, radicalmente surpreendente e assombroso que Lacan (1957/1998a) situa em seu grafo do desejo como a voz do "Che vuor?" (Lacan, 1957/1998a, p. 831). O contragolpe desse aniquilamento forma o terceiro supereu. 
Sobre o Che vuoi?, Lacan se serve dessa expressão a partir da novela de Jaques Cazotte (1992), O Diabo Enamorado, publicada originalmente em 1772. Na narrativa, que se passa nas ruínas de um palácio em Nápoles, Álvaro e seu amigo questionam a crença nos espíritos, atribuindo-a à fraqueza humana. Como demonstração de sua coragem, Álvaro evoca o diabo que the aparece sob a forma de uma cabeça de camelo provida de grandes orelhas, a pronunciar em italiano Che vuoi?, que queres?, e o diabo vai tomando a forma demandada. Lacan se interessa por essa pergunta indicando que é uma resposta antecipada que se mantém como interrogação para os sujeitos em sua relação com o Outro: "ficamos sempre ouvindo a interrogação do Che Vuoi? proferida por uma estranha cabeça de camelo metamórfico, de onde também pode sair a pequena cadela fiel do desejo" (Lacan, 1958-1959/2016, p. 374).

Freud (1917/1996e) faz uma aproximação entre a fantasia e uma reserva natural, local em que tudo é preservado e, de certo modo, apartado da realidade. Isso refere-se à característica da fantasia de propiciar um afastamento da realidade de renúncias pulsionais, permitindo ao sujeito criar "castelos no ar" (Freud, 1908/2015, p. 55). Para ele, as fantasias são fachadas psíquicas, impregnadas de desejo e construídas das coisas que são ouvidas em idade precoce. São ficções inconscientes que apartam o sujeito da realidade ao mesmo tempo em que lhe possibilitam não estar completamente desligado dela, pois possuem realidade psíquica (Freud, 1924/1996h). Constituem-se como substitutos da satisfação pulsional e, por isso, mantêm uma íntima conexão com a vida sexual (Freud, 1908/2015). Com "embelezamento" e "falseamento" dos fatos (Freud, 1892-1899/1996a, p. 296), promovem uma satisfação que a realidade insatisfatória não propiciaria (Freud, 1908/2015). Por isso mesmo, permitem ao neurótico suportar a castração - nome desse insuportável que a realidade evoca e sobre o qual as fantasias intervêm como proteção.

Mas, as fantasias, ao mesmo tempo, podem se tornar fonte de sofrimento pois mantêm o sujeito escravo das suas exigências, dependendo delas para se relacionar com a realidade (Freud, 1917/1996e). Essa dependência em relação às fantasias, leva a uma outra vertente - esta mais simbólica, pois indica uma certa lógica nessas fantasias. Trata-se da fantasia como uma instância que ordena o modo de vida dos sujeitos, o que está expresso na fantasia comum encontrada por Freud (1919/2016) entre seus pacientes, a de que "uma criança é surrada". Esta vertente traz uma redução da variedade de elementos a uma frase única, fundamental.

Há, ainda, uma outra vertente, esta concernente a um ponto de limite em relação ao dizer. Trata-se da dimensão de resíduo - cicatriz - que a fantasia apresenta e que a institui como uma marca determinante na maneira como os sujeitos enxergam o mundo. É, inclusive, essa dimensão o que leva Freud a preconizar a importância do trabalho de construção da fantasia, já que ela não pode ser "achada" nos confins do psiquismo. Assim, considerando essas três vertentes em que a fantasia se apresenta em Freud, bem como o modo de se operar sobre ela, conclui-se que é possível extrair uma lógica na fantasia. $E$, reconhecê-la evidencia como a fantasia - e o trabalho sobre ela - tem função 
central no tratamento psicanalítico, já que ela é determinante na maneira com a qual os sujeitos fazem suas escolhas, no modo como desejam e como enxergam o mundo.

No terceiro supereu, o Che vuoi? vai se fazer como algo totalmente novo e que já não tem mais a consistência de um censor persecutório. O Che vuoi?, nesse momento, abre uma pergunta que permite sair da resposta da apriorística que é a fantasia. Como esta não é mais suficiente, a pergunta se recoloca em termos de desejo. Há um atravessamento da fantasia, a partir de uma mudança na relação com o Outro, que passa a não ter a mesma consistência de antes.

Ao "não dirás uma palavra", proibição estabelecida após "abaixo o ministro!", o sujeito a enfrenta com uma segunda palavra "abaixo o ministro", destituindo o censor como tal. A pergunta sobre o desejo aparece, ao que ele responde com uma terceira palavra que o permite encontrar as coordenadas para transformar a insistência do segundo tempo em perseverança: "abaixo o ministro!". Do olhar, passa-se pelo pai e chega-se à dimensão da voz. Diante do vazio produzido pelo Che vuoi?, o sujeito é chamado a autorizar-se de si mesmo, fazendo valer sua palavra, não para o censor, mas para si próprio. Nesse sentido, não há um fim do supereu, mas sim, a possibilidade de se desalinhar dele (Campos, 2015). Mas, o que seria desalinhar-se do supereu, essa instância que como vocalização da pulsão de morte, "não tem remédio e nem nunca terá", como poetizou Chico Buarque de Holanda (1976).

O encontro com o analista pode permitir que o sujeito se desvencilhe de seu censor, questionando sua função. Insistir em sua palavra, endereçando-a ao analista, pode tornar a voz do supereu menos devastadora. Mas, se o analisando encarna essa voz no analista, nem por isso ele ocupa esse lugar. Como o analista o mantém vazio, algo novo pode advir. Convocado a insistir em sua palavra, o ser falante vai então poder manter em aberto o caminho para o Che Vuoi?, atravessando a resposta padronizada que era a da fantasia.

A travessia da fantasia permite que o sujeito não esteja mais tão submetido ao rigor de suas imposições. Tal expressão foi utilizada poucas vezes por Lacan, embora Jacques-Allain Miller tenha Ihe dado grande importância. Ao mencioná-la no Seminário 11, Lacan (1964/1998c) indica que se trata de uma travessia do plano das identificações, ou seja, do plano em que o sujeito fica tentando a todo custo se fazer amado pelo Outro. Ao final de uma análise, o Outro passa a não ser mais que um semblante. Isso só ocorre quando o sujeito consente com sua castração, com o furo estrutural no saber. Assim, o Outro perde sua consistência e há um "desvanecimento da demanda" (Miller, 2011, p. 22). Verifica-se, portanto, uma destituição subjetiva, experimentada como um "des-être", termo que no francês dá lugar a um des-ser e a um deserto (Lacan, 1964/1998c).

Santiago (2011) nos alerta para o fato de que o termo travessia é utilizado porque, quando se atravessa, não se destrói o que foi atravessado, passa-se para além. "Atravessar a fantasia não é efetuar seu desaparecimento, é simplesmente conhecer sua estrutura lógica e poder operar um ligeiro deslocamento, isto é, mudar de posição subjetiva" (Santiago, 2011, p. 11). Essa mudança refere-se a uma posição em que se esteja menos submetido a ela. 
Maurício Tarrab (2006), ao dar o testemunho de como foi sua análise diz que no final "o mel da fantasia torna-se então repugnante. Isso drena esse gozo, esvazia-o, deixa somente a significação, que então cai..." (Tarrab, 2006, p. 377). Assim como a fantasia não desaparece, o supereu não deixa de existir. Horne (2005) elabora que o final de uma análise é como a passagem de uma tragédia à comédia, já que o "dever ser" do supereu torna-se "ser", colocando-se à serviço da vida. Já não mais como ditador, mas como puro semblante, semblante para encobrir a relação sexual que não há.

Se na análise, o analisante localiza no analista a voz de seu supereu, com o final de análise, operação de separação do analista, esse supereu se desencarna, o que retorna para o sujeito. Alvarenga (2004) considera que, após a análise, o falasser tem sob a sua responsabilidade esse resíduo do supereu, que no seu caso se desdobrou em dois componentes. 0 primeiro refere-se ao analista como sintoma, parceiro da construção da psicanálise e que busca fazê-la avançar: "trata-se de uma escolha sintomática, um estilo de vida, do qual o sujeito retira, é claro, uma satisfação" (Alvarenga, 2004, p. 43). O segundo componente dá origem a um resíduo pulsional, de gozo, do qual o sujeito passa a "saber e haver-se com", um saber fazer com as manifestações do inconsciente, retirando daí certa satisfação, mas sem ceder de seu desejo. Esta refere-se à invenção do sinthoma, noção inventada por Lacan (1975-1976/2007) para nomear a amarração da realidade que permite ao sujeito fazer laço com o mundo, a partir de sua singularidade, seu modo próprio de satisfação.

Trata-se de uma identificação com isso que não desaparece e resta como irredutível do gozo. É, portanto, através de um saber pragmático adquirido na análise que vai se tornar possível ao falasser se virar com o que antes estava emaranhado na relação com o inconsciente e com o corpo (Santiago, 2011). Campos aborda o destino do supereu no final da análise, através de uma máxima que pode ser encontrada no "judô de Lacan: '[...]usar a força malévola do adversário superegoico a favor de seu próprio bem" (Campos, 2015, p. 214). Isso implica que o sujeito possa fazer um bom uso da pulsão que se encontra a sua disposição, ou, nas palavras de Lacan, "viver a pulsão" (Lacan, 1964/1998c, p. 258).

Ram Mandil, ao dizer sobre o final de sua análise, indica que "em muitos aspectos, a relação com o supereu está associada aos restos sintomáticos de uma análise" (Mandil, 2015, p. 249). O sujeito não vai se ver livre dele, mas, para Mandil, a análise o permitiu construir uma borda para seus "encontros matinais com o supereu" (Mandil, 2015, p. 250). Embora não seja possível pensar em um final de análise padrão e nem mesmo em uma propedêutica sobre o destino do supereu, sabemos que será necessária uma invenção para lidar com essa desencarnação do supereu, que antes encontrava lugar no analista. E isso somente pode ocorrer a partir de uma travessia no plano das identificações, pois se o eu busca ser amado pelo supereu, ao não precisar se fazer amado pelo Outro, é possível minimizar a força dessas injunções superegoicas.

\section{Notas}

Revista aSEPHallus de Orientação Lacaniana. Rio de Janeiro, 15(30), 101-122, mai. 2020 a out. 2020. 
1. O presente trabalho é fruto de uma articulação entre a pesquisa intitulada $O$ supereu em Freud e Lacan e seus destinos, orientada por Henri Kaufmanner e apresentada como Trabalho de Conclusão do Curso de Psicologia na PUC-MG, em 2005, e a dissertação de mestrado intitulada Da selva imaginária à fantasia fundamental: variações sobre a lógica da fantasia em Freud, orientada por Jésus Santiago e defendida no Programa de Pós-Graduação em Psicologia da UFMG, em 2014.

2. Lacan (1958-1959/2016) se dedica ao Hamlet, que nomeia como uma tragédia do desejo, para dizer que Hamlet não está atormentado pelo desejo por sua mãe, e sim, pelo desejo da mãe.

3. A primeira referência de Freud ao mito de Édipo foi na Carta 71 (Freud, 1892-1899/1996a) à Fliess, em 1897, quando relata que havia encontrado em si próprio sentimentos amorosos em relação à mãe e sentimentos de ciúmes em relação ao pai. Na missiva, escreve que a lenda grega captura uma "compulsão que toda pessoa reconhece porque sente sua presença em si mesma" (Freud, 1892-1899/1996a, p. 316). Lacan (1958-1959/2016) sintetiza esse Complexo em três tempos lógicos que promovem uma transformação da criança "assujeitada" em um "sujeito" que, por consentir com sua divisão, pode fazer parte do mundo como desejante.

\section{Referências Bibliográficas}

Alvarenga, E. (2004). O fim do Supereu. Clínica do Contemporâneo, (20), 41-44.

Araújo, G. de. (1990). O supereu em análise: O analista em questão. Letras da Coisa, (10), 83-95.

Barreto, F. P. (2001). A lei simbólica e a lei insensata: Uma introdução à teoria do supereu. Curinga, (7), 44-51.

Campos, S. de. (2015). Supereu, uerepus: Das origens aos seus destinos. Belo Horizonte: EBP.

Cazotte, J. (1992). O diabo enamorado. Rio de Janeiro: imago. (Trabalho original escrito em 1772)

Coelhos dos Santos, T. (2015, maio). O olhar sem véu: Transparência e obscenidade. Revista aSEPHallus de Orientação Lacaniana, 10(20), 4-15.

Coelho dos Santos, T., Santiago, J., \& Martello, A. (Orgs.). (2014). Os corpos falantes e a normatividade do supersocial. Rio de Janeiro: Cia de Freud.

Didier-Weill, A. (1997). Os três tempos da lei. Rio de Janeiro: Jorge Zahar Editor.

Freud, S. (1996a). Extratos dos documentos dirigidos a Fliess. In J. Strachey (Ed.), Edição Standard das Obras Psicológicas Completas de Sigmund Freud (Vol. 1). Rio de Janeiro: Imago. (Trabalho original publicado em 1892-1899).

Freud, S. (1996b). A interpretação dos sonhos. In J. Strachey (Ed.), Edição Standard das Obras Psicológicas Completas de Sigmund Freud (Vol. 4). Rio de Janeiro: Imago. (Trabalho original publicado em 1900). 
Freud, S. (1996c). Totem e tabu. J. Strachey (Ed.), Edição Standard das Obras Psicológicas Completas de Sigmund Freud (Vol. 13, pp. 13-192). Rio de Janeiro: Imago. (Trabalho original publicado em 1913).

Freud, S. (1996d). Sobre o narcisismo: Uma introdução. In J. Strachey (Ed.), Edição Standard das Obras Psicológicas Completas de Sigmund Freud (Vol. 14, pp. 82-119). (Trabalho original publicado em 1914).

Freud, S. (1996e). Conferência XXIII: Os caminhos da formação dos sintomas. In J. Strachey (Ed.), Edição Standard das Obras Psicológicas Completas de Sigmund Freud (Vol. 16, pp. 361-378). Rio de Janeiro: Imago. (Trabalho original publicado em 1917).

Freud, S. (1996f). Além do princípio de prazer. In J. Strachey (Ed.), Edição Standard das Obras Psicológicas Completas de Sigmund Freud (Vol. 18, pp. 17-72). Rio de Janeiro: Imago. (Trabalho original publicado em 1920).

Freud, S. (1996g). O Ego e o Id. In J. Strachey (Ed.), Edição Standard das Obras Psicológicas Completas de Sigmund Freud (Vol. 19, pp. 13-82). Rio de Janeiro: Imago. (Trabalho original publicado em 1923).

Freud, S. (1996h). O problema econômico do masoquismo. In J. Strachey (Ed.), Edição Standard das Obras Psicológicas Completas de Sigmund Freud (Vol. 19, pp. 179-190). Rio de Janeiro: Imago. (Trabalho original publicado em 1924).

Freud, S. (1996i). Inibição, sintoma e a angústia. In J. Strachey (Ed.), Edição Standard das Obras Psicológicas Completas de Sigmund Freud (Vol. 17, pp. 81-173). Rio de Janeiro: Imago. (Trabalho original publicado em 1926).

Freud, S. (1996j). Conferência XXXI: A dissecção da personalidade psíquica. In J. Strachey (Ed.), Edição Standard das Obras Psicológicas Completas de Sigmund Freud (Vol. 21, pp. 63-84). Rio de Janeiro: Imago. (Trabalho original publicado em 1932-1933).

Freud, S. (2010). Ensaios de metapsicologia. In Paulo Cesar Lima de Souza (Ed.), Obras Completas Vol.12. São Paulo: Companhia das Letras (pp. 13-194). (Trabalho original publicado em 1915).

Freud, S. (2015). O poeta e o fantasiar. In G. Iannini (Ed.), Arte, Literatura e os artistas: Obras Incompletas de Sigmund Freud. (pp. 53-68). Belo Horizonte: Autêntica. (Trabalho original publicado em 1908).

Freud, S. (2016). Bate-se numa criança: Uma contribuição para o estudo da origem das perversões sexuais. In G. Iannini (Ed.), Neurose, Psicose, Perversão: Obras Incompletas de Sigmund Freud. (pp. 123-156). Belo Horizonte: Autêntica. (Trabalho original publicado em 1919).

Freud, S. (2017). A análise finita e a infinita. In G. Iannini (Ed.), Fundamentos da clínica psicanalítica (pp. 315-364). Belo Horizonte: Autêntica. (Trabalho original publicado em 1937). 
Freud, S. (2020). O mal-estar na cultura. In G. Iannini (Ed.), O mal-estar na cultura e outros escritos. Obras Incompletas de Sigmund Freud. (pp. 305-410). Belo Horizonte: Autêntica. (Trabalho original publicado em 1930).

Gerez-Ambertín, M. (2003). As vozes do supereu na clínica psicanalítica e no mal-estar na civilização. São Paulo: Editora de Cultura.

Holanda, C. B. de. (1976). O que será, à flor da pele. In: M. Nascimento. De volta ao começo. Rio de Janeiro: Phonogram.

Horne, B. (2005, Janeiro 02). El superyo en el final de analisis [Postagem web log]. Retirado de http://www.lacanian.net/Ornicarl\%20online/Archive\%200D/ornicar/articles/171hor.html

Kant, I. (2004). Fundamentação da Metafísica dos Costumes. São Paulo: Martin Claret.

Lacan, J. (1979). O Seminário, Livro 1: Os escritos técnicos de Freud. Rio de Janeiro: Jorge Zahar Editor. (Trabalho original publicado em 1954).

Lacan, J. (1985). O Seminário, Livro 20: Mais, ainda. Rio de Janeiro: Jorge Zahar Editor. (Trabalho original publicado em 1972-1973).

Lacan, J. (1987). Da psicose paranoica em suas relações com a personalidade. Rio de Janeiro: Forense-Universitária. (Trabalho original publicado em 1932).

Lacan, J. (1991). O Seminário, Livro 8: A transferência. Rio de Janeiro: Jorge Zahar Editor. (Trabalho original publicado em 1960-1961).

Lacan, J. (1995). O Seminário, Livro 4: A relação de objeto. Rio de Janeiro: Jorge Zahar Editor. (Trabalho original publicado em 1956-1957).

Lacan, J. (1998a). A instância da letra ou a razão desde Freud. In J. Lacan, Escritos (pp. 496-533). Rio de Janeiro: Jorge Zahar Editor. (Trabalho original publicado em 1957).

Lacan, J. (1998b). Observação ao Relatório de Daniel Lagache. In J. Lacan, Escritos. (pp. 653-691). Rio de Janeiro: Jorge Zahar Editor. (Trabalho original publicado em 1960).

Lacan, J. (1998c). O Seminário, Livro 11: Os quatro conceitos fundamentais da psicanálise. Rio de Janeiro: Jorge Zahar Editor. (Trabalho original publicado em 1964).

Lacan, J. (2002). O Seminário 26: La topología e el tiempo [CD-ROM, Windows]. (Trabalho original publicado em 1978-1979).

Lacan, J. (2003). Televisão. In J. Lacan, Outros escritos (pp. 508-543). Rio de Janeiro: Jorge Zahar Editor. (Trabalho original publicado em 1973).

Lacan, J. (2007). O Seminário, Livro 23: O Sinthome. Rio de Janeiro: Jorge Zahar Editor. (Trabalho original publicado em 1975-1976)

Lacan, J. (2016). O Seminário, Livro 6: O desejo e sua interpretação. Rio de Janeiro: Jorge Zahar Editor. (Trabalho original publicado em 1958-1959).

Mandil, R. A. (2015). O supereu ao final de análise. In S. Campos. (Org.), Supereu: Das origens aos seus destinos. Belo Horizonte: EBP. 
Miller, J.-A. (2009). Clínica del superyó. In J.-A. Miller, Conferências Porteñas (pp. 127-142). Buenos Aires: Paidós.

Miller, J.-A. (2011). Donc, la lógica de la cura. Buenos Aires: Paidós.

Santiago, J. (2011). A fantasia como um nome dos limites do simbólico. Opção Lacaniana, (61), 3136.

Santiago, J. (2020, novembro). Cristianismo, um supereu todo-amor. Orientação Lacaniana, Belo Horizonte, Minas Gerais, Brasil. (Trabalho inédito cedido gentilmente pelo autor).

Scheijtman, F. (2004, julho). O supereu: Caroço do pai. Letra Clínica, (1), 13-22.

Tarrab, M. (2006). E o sopro torna-se signo. Opção Lacaniana, (46), 377-345.

Citação/Citation: Célia Carvalho da Silva, V. (mai. 2020 a out. 2020). Perspectivas Clínicas do Supereu: desdobramentos desse imperativo categórico no tratamento psicanalítico. Revista aSEPHallus de Orientação Lacaniana, 15(30), 101-122. Disponível em www.isepol.com/asephallus. Doi: 10.17852/1809709x.2020v15n30p101-122

Editor do artigo: Tania Coelho dos Santos.

Recebido/Received: 04/03/2020 / 03/04/2020.

Aceito/Accepted: 04/20/2020 / 20/04/2020.

Copyright: (C) 2019 Associação Núcleo Sephora de Pesquisa sobre o moderno e o contemporâneo. Este é um artigo de livre acesso, que permite uso irrestrito, distribuição e reprodução em qualquer meio, desde que o autor e a fonte sejam citados/This is an open-access article, which permites unrestricted use, distribution, and reproduction in any medium, provided the author and source are credited. 